Revista de
Economild
Contemporâned

\title{
HOW EMPLOYMENT SHAPES INCOME INEQUALITY: A COMPARISON BETWEEN BRAZIL AND THE U.S.
}

\author{
Alexandre Gori Maia ${ }^{a}$ \\ Arthur Sakamoto ${ }^{b}$ \\ Sharron Xuanren Wang \\ ${ }^{\text {aP }}$ rofessor at the University of Campinas, Department of Economics. Campinas, SP, Brazil. ORCID: \\ https://orcid.org/0000-0003-0075-5094.

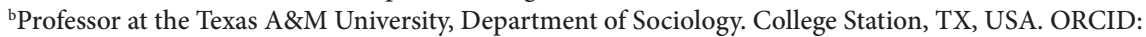 \\ https://orcid.org/0000-0002-1292-8274. \\ 'Professor at the Delaware State University, Dover, DE, USA. ORCID: \\ https://orcid.org/0000-0001-5102-2478.
}

Manuscript received on 2018/03/23 and accepted for publication on 2019/04/04.

\begin{abstract}
In this study, we analyze the relationship between the development of occupational structure and income inequality in Brazil and the U.S. While both Brazil and the U.S. face high levels of inequality, low socioeconomic development in Brazil notably reduces the proportion of total income that accrues in the bottom two quintiles of the income distribution. In the U.S., inequality is mostly due to unobserved differences within occupations and has grown in large part because of higher earnings among highskilled workers. Our results highlight that the effects of occupational structure are generally more pronounced at lower levels of economic development. At the higher level of economic development found in the U.S., inequality appears to increase largely due to rising inequality among high-skilled employees, which may be a function of unobserved organizational variables such as firm productivity and market advantage.
\end{abstract}

KEYWORDS: inequality decomposition; occupation; middle class; labor market.

JEL CODES: J82; J24; O15.

Corresponding author: Alexandre Gori Maia

E-mail address: gori@unicamp.br 


\section{COMO O EMPREGO DEFINE A DESIGUALDADE DE RENDA: UMA COMPARAÇÃO ENTRE O BRASIL E OS ESTADOS UNIDOS}

RESUMO: Neste estudo, analisamos a relação entre o desenvolvimento da estrutura ocupacional e a desigualdade de renda no Brasil e nos Estados Unidos. Enquanto os dois países apresentam elevados índices de desigualdade, o baixo desenvolvimento socioeconômico no Brasil reduz sensivelmente a proporção da renda total apropriada pelos quintos inferiores da distribuição de renda. Nos Estados Unidos, a desigualdade é devida principalmente a diferenças intra-ocupacionais e tem crescido, em grande medida, devido aos elevados rendimentos de algumas categorias profissionais mais qualificadas. Nossos resultados destacam que os efeitos da estrutura ocupacional na desigualdade seriam mais pronunciados nos estágios inferiores de desenvolvimento. Nos estágios mais elevados de desenvolvimento, como observado nos Estados Unidos, a desigualdade cresceria principalmente devido aos elevados rendimentos de profissionais mais qualificados, o que seria um resultado de variáveis organizacionais não observáveis, como produtividade da firma e vantagens de mercado.

PALAVRAS-CHAVE: decomposição da desigualdade; ocupação; classe média; mercado de trabalho. 


\section{INTRODUCTION ${ }^{1}$}

Brazil and the U.S. provide an interesting comparison for understanding the effect of employment dynamics on income inequalities. While these countries share certain historical similarities in terms of demographics and their processes of colonial exploitation, Brazil and the U.S. nonetheless underwent very different trajectories of social, economic, and institutional development (ACEMOGLU and ROBINSON, 2012; FURTADO, 1989). In the $21^{\text {st }}$ century, Brazil and the U.S. are known as the two largest economies and populations of the Americas, with high levels of domestic inequality but notably different levels of socioeconomic development.

The latter societal characteristic is generally believed to be closely related to occupational structure, which is fundamentally a proximate determinant of earnings (TREIMAN, 1970). A comparison of trends in inequality and occupational structure in Brazil and the U.S. provides a broader perspective for understanding both the significance of occupation in shaping labor market structure, and occupation as it relates to inequality. In general, occupational structure is an essential aspect of production organization, and it reflects the level of technological development, the demand for various products and services, as well as the supply and demand for different skills (BANERJEE, 2015; BLAU and DUNCAN, 1966; ROSE and HARRISON, 2007).

We investigate the relationship between the development of occupational structure and income inequality in Brazil and in the U.S. Specifically, we explore: (i) how the development of occupational structure defines different levels of income inequality; and (ii) how the dynamics of occupational structure have diverse impacts on inequality, depending on the level of socioeconomic development. Compositional differences in occupational structure (i.e., low-skilled, middle-skilled, and high-skilled) and their effects on income inequality are clearly evident when contrasting these national labor markets. Varying levels of within-occupation inequality are also likely to be evident, which would be related to the demand for various unobservable skills within occupational groups.

\footnotetext{
1 We thank FAPESP (Fundação de Amparo à Pesquisa do Estado de São Paulo, Grant 2014/09678-2) for supporting this research. We also thank our anonymous reviewers for their recommendations.
} 


\section{HISTORICAL BACKGROUND}

The occupational structure of Brazil largely reflects its relative level of economic underdevelopment. Labor productivity is substantially lower in Brazil than in the U.S., as are average wages and the employment of high-skilled labor (MAIA and MENEZES, 2014). The oversupply of unskilled workers in Brazil limits opportunities for upward mobility associated with a more bifurcated occupational structure (ULYSSEA, 2006). Income inequality is likely a function of the segmentation between a large sector of unskilled occupations and relatively fewer high-status occupations that employ highskilled workers who are relatively scarce in Brazil (MAIA, 2013).

Inequalities associated with this labor market bifurcation are further exacerbated by uneven regional development, extreme variation in educational opportunities, and highly imperfect credit markets or capital financing. All these factors contribute to substantial variation in firm organization and technology utilization in both traditional subsistence sharecropping and large-scale corporate farming. Economic growth is essential to reducing labor market bifurcation and generating better opportunities to increase incomes and improve employment in Brazil (BOURGUIGNON and FERREIRA, 2007; CRISTINA and ALMEIDA, 2012).

However, despite recent improvements, Brazil still faces important bottlenecks to economic development. The most-cited bottleneck is the low level of human capital such as education, job training, and health - which severely restricts labor productivity and reduces social mobility (FERREIRA and GIGNOUX, 2011; FERREIRA and VELOSO, 2006; PINHEIRO et al., 2004). Other constraints highlighted by the economics literature include: the development of legal institutuions such as the cumbersome regulatory framework in business and labor markets (CAVALCANTI, MAGALHÃES and TAVARES, 2008); poor investment in infrastructure, such as transport connectivity, sanitation services, and access to information and communication technologies (MOUROUGANE and PISU, 2011); the vastly unequal distribution of wealth and political power (ENGERMAN and SOKOLOFF, 1994); and more broadly, the inclusiveness of economic and political institutions (ACEMOGLU and ROBINSON, 2012).

When contrasted with Brazil, the U.S. occupational structure is post-industrial and more heavily invested in specialized services associated with a very high division of labor and heightened productivity. In the $21^{\text {st }}$ century, new information and communication technologies have been applied throughout much of the U.S. occupational structure to improve productivity and monitor worker performance more closely. Associated with this expanding service-based economy is the increased employment of various managers, professionals, and specialized technicians, while the 
significance of agricultural and manufacturing jobs in the U.S. economy has receded. Some theorists have described this type of modern economy as an information society (CASTELLS and AOYAMA, 2002) because specialized knowledge, high-skilled employment, and the development of advanced technology are increasingly key sources of productivity growth and wealth generation (BELL, 1976).

In the post-industrial, service-oriented U.S. economy, the division of labor is often very high. Labor and firm performance are systematically monitored by information technologies, and market competition is typically intense. Management is generally under constant economic pressure to expand production, increase profits, or promote innovation in either technology or the social organization of the firm. Capital financing is quickly withdrawn from underperforming companies, which, in turn, enhances market competition. In contrast with Brazil's expansive civil service, which provides long-term employment at relatively high wages and attractive benefits, governmental agencies in the U.S. are usually under political pressure to follow private sector business models or to downsize via 'privatization'.

In this context of constant pressure to improve productivity, Autor, Levy, and Murnane (2003) argue that a certain extent of polarization of the U.S. occupational structure has been taking place due to technological change. Computerized technologies can often perform routine activities, which results in a decline in employment of many middle-level occupations such as bank tellers (displaced by ATMs), ticketing and sales agents (displaced by online ordering), bookkeepers and administrative workers (displaced by automated software), and lower-level technicians and professionals (displaced by specialized computer applications). Consequently, occupational structure becomes more heavily characterized by employment in jobs that cannot be readily performed by computers that follow a specified series of instructions and therefore facilitate automation.

Such jobs often include lower-level service occupations that may also involve a manual component (e.g., cleaning, cooking, gardening, repair services, construction), in addition to professional jobs that involve creativity or artistic sensitivity, complex problem solving or analysis, idiosyncratic or non-routine judgment, and certain managerial activities that require extensive social skills. As a result, the U.S. occupational structure has become somewhat polarized, as it continues to add higherlevel jobs (e.g., managerial and professional employment) and lower-level jobs (lessskilled service employment) while reducing traditional middle-level jobs. Nonetheless, this polarization is related to the U.S. experience of middle-class employment and it is small in comparison to the bifurcated occupational structure of Brazil.

In contrast to the relatively modest compositional effect of the changing occupational structure, Kim and Sakamoto (2008) argue that wage inequality is also on the rise within 
occupations (i.e., increasing occupation-specific rates of inequality) in the U.S. The authors posit that due to firm-level changes in employment relations, wage inequality is increasingly dependent on the bargaining power of a worker within his or her firm and the degree to which the firm earns market rents. This interaction operates throughout much of the occupational structure and generally increases the returns to a worker's human capital, productivity, and education (such as a college diploma). As inequality increases in the labor force, a large portion likely occurs within occupations.

\section{RESEARCH METHODS}

\subsection{DATA}

We pooled annual data from the Brazilian Pesquisa Nacional por Amostra de Domicílios (PNAD) survey, conducted by the Instituto Brasileiro de Geografia e Estatística (IBGE), and the American Current Population Survey (CPS), conducted by the U.S. Census Bureau. These two annual household surveys are widely used and representative of their respective labor forces. Our investigation includes data from 1983 through 2013. ${ }^{2}$ With respect to the CPS, we only used files from March (i.e., the Annual Social and Economic Supplement - ASEC).

Income values in the PNAD refer to the self-reported monthly income generally received in the reference year, whereas the CPS provides self-reported annual income and earnings. We divided this CPS annual figure by 12 to obtain a monthly income comparable to that of the Brazilian monthly values. We deflated nominal values to July of 2013 using the Índice Nacional de Preços ao Consumidor (INPC) from Brazil and the CPI (i.e., Consumer Price Index for Urban Consumers) from the U.S. Subsequently, we converted Brazilian earnings to international purchasing power parity (PPP) dollars using the exchange rate available at the World Data Bank. ${ }^{3}$ PPP dollars serve as both currency converters and spatial price deflators that equalize the purchasing power of different currencies (TAYLOR, 2003).

An inconvenience in analyzing a time series of income distribution in the U.S. is the change in methodology by the Census Bureau to censor the income of individuals at the

2 Between 1983 and 2011, the PNAD was not conducted in 1991, 1994, 2000, and 2010. These years are therefore excluded from our analysis for Brazil.

3 On July $1^{\text {st }} 2013$, the exchange rate was 1.81 Brazilian Reais to every PPP international dollar (THE WORLD BANK, 2017). 
highest top-coded levels (LARRIMORE et al., 2008). Prior to March of 1996, the censorship limited the income values to be no greater than a specified maximum value. Between 1996 and 2010, the Bureau modified its censorship method, substituting all values above the maximum value (topcode) with a mean value. In 2011, the Census Bureau developed a new method to preserve the income distribution above the topcode. To allow for a more consistent historical analysis of income and earnings distribution, we used a series of ASEC files released by the Census Bureau that apply the same methodology to specify the highest top-coded income values between 1975 and $2010{ }^{4}$

Additionally, we applied an equivalence scale to account for varying needs among households of different sizes. Equivalence is an important consideration when comparing well-being between and within countries, as larger families have more needs and greater economies of scale with regard to their standard of living (BURKHAUSER, SMEEDING and MERZ, 1996). We adopted an exponential scale based on the methods of Buhmann et al. (1988), which may be summarized by the following equation:

$$
Y=\frac{H}{S^{e}}
$$

In (1), $Y$ refers to the equivalized income; $H$ refers to the total household income; $S$ refers to the household size; and $e$ is the elasticity of scale rate (ranging from 0 to 1 ). The higher the value of $e$ (i.e., the closer to 1), the lower the economies of scale. Based on the values more commonly found in international studies, we adopted a value of $e$ equal to 0.5 to yield an intermediate level of economies of scale (BURKHAUSER, SMEEDING and MERZ, 1996).

We analyzed the dynamics of both the equivalized income of the total population and the earnings of the employed population. Employed respondents were defined as those who were 16 years old or older during the reference week and either: (i) did any work at all (at least 1 hour) as paid employees, worked in their own business, profession, or farm, or worked 15 hours or more as unpaid workers in an enterprise operated by a family member; or (ii) were not working, but had a job or business from which they were temporarily absent. Those working for the Armed Forces or who did not have positive earnings were not included in our analyses.

Based on Maia and Sakamoto (2015), we developed an occupational typology that can be applied in both the Brazilian and U.S. labor markets. We classified the occupation codes provided by PNAD and CPS into common occupational groups in Brazil and

4 This methodology is explained at <https://cps.ipums.org/cps/income_cell_means.shtml/>. Accessed on: Aug. $4^{\text {th }}, 2015$. 
the U.S. The classification considers skills, education, training, and credentials reflecting prestige, power, and earnings. We used 20 two-digit occupational groups. These 20 occupational groups could be further aggregated into six one-digit categories, including: (1) managers, (2) professionals, (3) technical and specialist employees, (4) sales and laborers, (5) lower-level service workers, and (6) farming and agricultural workers. Specifically, management occupations included bosses; managers; and firstline supervisors. Professionals included legal occupations (e.g., lawyers, judges, legal assistants); biological and health scientists (e.g., agricultural, biological, health); math and related scientists (e.g., computer, mathematics, engineering); social and human scientists (e.g., financial specialists, social scientists, those working in social services); and education and library sciences (e.g., teachers, instructors, librarians). Specialists included those working in entertainment and related areas (e.g., arts, design, entertainment, sports, and media); technicians (e.g., technologists and technicians of several areas); clerks (e.g., official clerks, office managers, administrative assistants); protective services (e.g., firefighters, police officers, criminal investigators); and customer service workers (e.g., customer service representatives, receptionists). Sales and laborers consisted of those working in sales (e.g., retail sales, cashiers, sales representatives); those in installation and repair (e.g., installation, maintenance, and repair); construction and extraction jobs (e.g., masons, carpenters, painters); production jobs (e.g., assembly, manufacturing, operation); and transportation and moving jobs (e.g.; bus and truck drivers, related laborers in transport and materials moving). Low-paid services included personal care and related areas (e.g., hairdressers, personal care aids); food service (e.g., cooks, servers, food preparation workers); and building maintenance and cleaning (e.g., housekeepers, cleaning staff). Farming occupations included farming, fishing, and forestry occupations.

\subsection{STATISTICAL METHODS}

\subsubsection{DECOMPOSING THE VARIATION IN EQUIVALIZED INCOME INEQUALITY}

We first used the Gini index to analyze inequality in the distribution of equivalized income. The Gini index is a standardized measure $(0 \leq G \leq 1$, when $n$ is large) based on a concentration function known as the Lorenz curve. In our study, the curve represents the relationship between the cumulative proportion of equivalized income ( $Y$-axis) and the cumulative proportion of the population ( $X$-axis). Specifying the area between the Lorenz curve and the $X$-axis as $\beta$, the Gini index may be written as: 


$$
G=1-2 \beta
$$

As equivalized income depends on total household income, which is composed of different income types and sources, we decomposed the Gini index to consider the contribution of each income source to total equivalized household income inequality. Therefore, the Gini index can be represented by the weighted sum of concentration ratios $\left(C_{s}\right)$ observed for each source of income. More specifically, as discussed by Hoffmann (2004):

$$
G=\sum_{s=1}^{k} p_{s} C_{s}
$$

In (3), $p_{s}$ is the participation of the $s^{\text {th }}$ source of total income $\left(\Sigma Y_{s} / \Sigma Y\right)$, and $C_{s}$ is its respective concentration ratio that can be given by:

$$
C_{s}=1-2 \beta_{s}
$$

Similar to the Gini index, the concentration ratio $\left(-1<C_{s}<1\right)$ is based on a specific concentration curve for each income type (or income source). The difference in the concentration ratio is that the cumulative concentration of income on the $Y$-axis is now represented by the cumulative concentration of the source of income $s$, holding constant the prior ranking total income on the $X$-axis. That is, this specific concentration curve relates the concentration of the $s^{\text {th }}$ income source ( $Y$-axis) and the equivalent percentile of the $i^{\text {th }}$ individual, according to the individual's total income. The coefficient $\beta_{s}$ thus represents the area between the $s^{\text {th }}$ concentration curve and the $X$-axis.

Equations (3) and (4) show that the Gini index can be divided into $k$-components $(s=1, \ldots, k)$. For example, total inequality as measured by the Gini index may be decomposed into income from labor $(s=1)$ and income from all other sources $(s=2)$. Based on these expressions, we can also represent the difference in the Gini index between two periods $\left(\Delta G=G_{1}-G_{0}\right.$, for $t=0$ and $\left.t=1\right)$ as a function of: (1) changes in the composition of the income sources $\left(\Delta p_{s}\right)$; and (2) changes in the concentration ratios of the income sources $\left(\Delta C_{s}\right)$. Initially, the difference in the Gini index is a function of the weighted concentration ratios (HOFFMANN, 2001).

$$
\Delta G=\sum_{s=1}^{k}\left[p_{1 s} C_{1 s}-p_{0 s} C_{0 s}\right]
$$


Adding and subtracting $p_{0 s} C_{1 s}$, we then obtain:

$$
\begin{gathered}
\Delta G=\sum_{s=1}^{k}\left\{p_{1 s} C_{1 s}+p_{0 s} C_{1 s}-p_{0 s} C_{1 s}-p_{0 s} C_{0 s}\right\} \\
\Delta G=\sum_{s=1}^{k}\left\{C_{1 s} \Delta p_{s}+p_{0 s} \Delta C_{s}\right\}
\end{gathered}
$$

Alternatively, if we add and subtract $p_{1 s} C_{0 s}$ in equation (5) then we have:

$$
\Delta G=\sum_{s=1}^{k}\left\{C_{0 s} \Delta p_{s}+p_{1 s} \Delta C_{s}\right\}
$$

Equations (7) and (8) represent two alternative ways of decomposing variation in the Gini index. The mean of these equations provides a suitable solution for avoiding any arbitrary choice between these expressions:

$$
\Delta G=\sum_{s=1}^{k}\left[\overline{C_{s}} \Delta p_{s}+\bar{p}_{s} \Delta C_{s}\right]
$$

In (9), $\bar{C}_{s}, \bar{G}$, and $\bar{p}_{s}$ represent the average values for the respective measures in the two periods. After algebraic manipulation, equation (9) can be expressed by (HOFFMANN, 2001):

$$
\Delta G=\sum_{s=1}^{k}[\underbrace{\left(\overline{C_{s}}-\bar{G}\right) \Delta p_{s}}_{\text {composition }}+\underbrace{\bar{p}_{s} \Delta C_{s}}_{\text {inequality }}]
$$

The first term in (10) represents the composition effect, which is the share of the difference in the Gini index that is due to changes in the proportion of income accumulated by each source. The second term represents the inequality effect, which is the share of the difference in the Gini index that is due to changes in the concentration ratio of each income source.

\subsubsection{DECOMPOSING THE DIFFERENCE IN INDIVIDUAL EARNINGS INEQUALITY}

We performed specific analyses for individual earnings inequality in the labor market using the Theil indicator. Suppose $Y_{i}$ refers to the $i^{\text {th }}$ individual's earnings in a population of size $n$, while $Y$ refers to total earnings. The Theil index $(0 \leq T<\ln n)$ will be given by (HOFFMANN, 1998): 


$$
T=\sum_{i=1}^{n} \frac{Y_{i}}{Y} \ln n \frac{Y_{i}}{Y}
$$

Both the Theil and Gini indices satisfy the Pigou-Dalton condition, meaning that they will increase in value for regressive transfers of income. The Gini index is relatively more sensitive to changes in intervals with a higher frequency density, which are generally found in the middle of the income distribution. In this respect, the Theil index is more sensitive than the Gini index to changes occurring in the lower and upper bounds of the income distribution.

A major advantage of the Theil indicator is that it can be linearly decomposed into two main components: (i) differences between groups and (ii) differences within groups. For example, if an employed population is divided into occupational groups, total earnings inequality can be represented by the sum of the inequality due to earnings differences between the occupational groups $(B)$ and inequality due to earnings differences within the occupational groups $(W) . B$ and $W$ will be given by (HOFFMANN, 1998):

$$
\begin{aligned}
T & =B+W \\
B=\sum_{j=1}^{g} \frac{Y_{j}}{Y} \ln \frac{Y_{j} / Y}{n_{j} / n} & =\sum_{j=1}^{g} p_{j} \ln \frac{p_{j}}{n_{j} / n}=\sum_{j=1}^{g} p_{j} B_{j} \\
W & =\sum_{j=1}^{g} p_{j} W_{j}
\end{aligned}
$$

In (13), $Y_{j}$ is total earnings of the $j^{\text {th }}$ occupational group; $p_{j}$ is the respective share of total earnings; $n j$ is the respective population; and $B_{j}$ is a measure of the asymmetry between the share of the total income $\left(p_{j}\right)$ and the share of the total population $\left(n_{j} / n\right)$ of the $j^{\text {th }}$ occupational group. In (12) and (14), $W_{j}$ is a measure of inequality within the $j^{\text {th }}$ occupational group and is computed similarly to equation (11), restricting our analysis to the population of the $j^{\text {th }}$ occupational group.

We can also evaluate the extent to which differences in the Theil index in a given period $(\Delta T)$ were due to changes in the differences between the groups $(\Delta B)$ versus changes in the differences within groups $(\Delta W)$. More specifically, we use the following expression:

$$
\begin{gathered}
\Delta T=\Delta B+\Delta W \\
\Delta T=\sum_{j=1}^{g}[\underbrace{\Delta\left(p_{j} B_{j}\right)}_{\text {between }}+\underbrace{\Delta\left(p_{j} W_{j}\right)}_{\text {within }}]
\end{gathered}
$$


The first term on the right-hand side of equation (16) represents the share of the difference in the Theil indicator that is attributed to changes in the between-group component. Groups can contribute to changes in inequality through changes in their share of occupational structure $\left(\Delta p_{j}\right)$ or changes in the ratio between the accumulation of earnings and population $\left(\Delta B_{j}\right)$. The second term represents the contribution of changes in the within-group component of the $j^{\text {th }}$ group. Similarly, groups can modify within-group inequality through changes in their share of occupational structure $\left(\Delta p_{j}\right)$ or changes in the level of inequality within these groups $\left(\Delta W_{j}\right)$.

Expressions (12) through (14) can also be extended to consider additional levels of disaggregation. If we suppose that in addition to $g$ occupational groups, the population is further divided into $d$ groups of education, we can represent the inequality indicators of $B$ and $W$ for two levels of disaggregation by:

$$
\begin{aligned}
B^{2} & =\sum_{j=1}^{g} \sum_{l=1}^{d} p_{j l} B_{j l} \\
W^{2} & =\sum_{j=1}^{g} \sum_{l=1}^{d} p_{j l} W_{j l}
\end{aligned}
$$

In (17), $B^{2}$ represents the share of total inequality due to the differences between all combinations of the two variables under analysis - occupations and education. $W^{2}$ represents the share of total inequality due to the differences within these combinations of groups. The greater the value of $B^{2}$, the higher the explanatory power of differentials between these groups relative to within-group differentials.

The marginal contribution of a variable represents the share of the total betweengroup inequality that can only be explained by its respective groups. This can be readily computed by comparing two measures of between-group inequality. First, we consider all combinations of groups (unrestrictedB). Next, we excluded the combination for the specific groups of interest (restricted $B$ ). For example, the marginal contribution of the $d$ groups of education $\left(B_{d}\right)$ will then be given by:

$$
\beta_{d}=\underbrace{\sum_{j=1}^{g} \sum_{l=1}^{d} p_{j l} B_{j l}}_{\text {unrestricted }}-\underbrace{\sum_{j=1}^{g} p_{j} B_{j}}_{\text {restricted }}
$$

As a result, the marginal contribution of education $\beta_{d}$ is equal to the total betweengroup inequality considering all groups of disaggregation, minus the between-group inequality, which does not consider the disaggregation for education groups. 
Equations (17) through (19) can also be easily extended to a multi-variable analysis. In this study, we consider five socio-demographic variables. The first is occupation, as represented by 20 two-digit occupational groups. The second variable is educational attainment, defined by four groups (i.e., primary school or less; unfinished secondary school; secondary school diploma; higher education diploma). The third variable is age as categorical variables (i.e., 16-19; 20-29; 30-39; 40-49; 50-59; 60 or older). The fourth variable is sex (i.e., female; male). The last variable is race (e.g., black; white; other).

\section{EMPIRICAL RESULTS}

\subsection{THE CONTRIBUTION OF LABOR INCOME INTOTAL INEQUALITY}

The combined populations of Brazil and the U.S. constitute more than one-half of a billion people living in the Americas. Both of these populations were characterized by extreme levels of socioeconomic inequality in 2013 (as shown in Table 1). However, changes in the countries' socioeconomic structure over the last 30 years were more pronounced in Brazil. For example, the population in Brazil increased by $60 \%$ between 1983 and 2013, but by only 36\% in the U.S during the same period. The reduction in the average number of members per household in Brazil was also significant (from 4.4 in 1983 to 3.1 in 2013, which represents a decrease of 31\%), and primarily a consequence of the rapid decline in the country's fertility rate in the 1980s and 1990s (MAIA and SAKAMOTO, 2015). As a result of both demographic and economic changes, per capita income in Brazil grew substantially, reducing the huge differences in income relative to the U.S. In 2013 in Brazil, 197 million people were living with a per capita income of US\$ 587 per month, which was more than double incomes in 1983 (US\$ 286 per month), but still four times lower than per capita income in the U.S. in 2013 (US\$ 2,345 per month). Income differences between the two countries are also substantial after controlling for the economies of scale enjoyed by larger families in Brazil. Equivalized income, which controls for differences in family sizes, grew 73\% in Brazil and only $23 \%$ in the U.S. from 1983 to 2013, although income remains 3.7 times higher in the latter country compared to the former. 
Table 1 - Demographic and Inequality Indicators, Brazil and the U.S., 1983/2013

\begin{tabular}{|c|c|c|c|c|}
\hline \multirow{2}{*}{ Indicator } & \multicolumn{2}{|c|}{ Brazil } & \multicolumn{2}{|c|}{ U.S. } \\
\hline & 1983 & 2013 & 1983 & 2013 \\
\hline Population (1,000 people) & 123,393 & 197,497 & 229,587 & 311,116 \\
\hline Persons/household & 4.4 & 3.1 & 2.7 & 2.5 \\
\hline Per capita income & 286 & 587 & 1,862 & 2,345 \\
\hline Equivalized income & 597 & 1,031 & 3,145 & 3,863 \\
\hline \multicolumn{5}{|c|}{ Percentile of equalized income } \\
\hline 40 & 249 & 553 & 2,175 & 2,319 \\
\hline 50 & 321 & 664 & 2,623 & 2,917 \\
\hline 90 & 1,321 & 2,032 & 5,974 & 7,502 \\
\hline 99 & 4,258 & 6,795 & 12,059 & 18,333 \\
\hline \multicolumn{5}{|l|}{$\%$ Share of total income } \\
\hline Poorest $40 \%$ & 9.5 & 12.4 & 14.9 & 13.2 \\
\hline $50 \%$ & 46.9 & 48.5 & 56.8 & 54.6 \\
\hline $9 \%$ & 32.4 & 28.5 & 22.8 & 23.9 \\
\hline Richest 1\% & 11.3 & 10.5 & 5.5 & 8.3 \\
\hline Gini Index (\%) & 56.0 & 49.6 & 38.8 & 44.8 \\
\hline
\end{tabular}

Source: Authors' elaboration based on data from PNAD (IBGE) and CPS (BLS).

In addition to vast differences in average incomes, the gap between levels of inequality within these countries is also substantial. Although both countries are characterized by ordinate levels of inequality, it remains significantly higher in Brazil. In Brazil, the share of total income accumulated by the poorest $40 \%$ was only 1.9 percentage points higher than the share accumulated by the $1 \%$ richest households in the country, even after factoring out the economies of scale of larger families (via equivalized income, which tends to reduce income inequality since poor families are on average larger than rich families). The income accumulated by the richest $10 \%$ was 3.1 times higher than the share accumulated by the Brazilian poorest $40 \%$ in 2013 . Differences are less extreme in the U.S., where the ratio between the share of equivalized income accumulated by the richest $10 \%$ and the poorest $40 \%$ was 2.2 in 2013 and the Gini index for the distribution of equivalized income during the same year was 4.8 percentage points lower than that in Brazil.

One main characteristic of the high levels of inequality in Brazil is the extreme concentration of people within the lower bound of the income distribution. As a result, differences in equivalized income between Brazil and the U.S. are higher at the lower 
and middle percentiles than at the higher percentiles of the distribution. For example, in 2013 the $40^{\text {th }}$ percentile for equivalized income in the U.S. was 4.2 times higher than that in Brazil, while the $90^{\text {th }}$ percentile was 3.7 times higher, and the $99^{\text {th }}$ percentile was only 2.7 times higher. The differentials in 1983 were more dramatic, when the $40^{\text {th }}$ percentile in the U.S. was 8.7 times higher than that in Brazil, and the $90^{\text {th }}$ percentile in the U.S. was 4.5 higher.

The reduction in differences between Brazil and the U.S. is the result of opposite trends in the dynamics of inequality during this period. Inequality declined sharply in Brazil, particularly in the 2000s. For example, the Gini index for the distribution of equivalized income fell $11 \%$ between 2001 and 2013 (or 6 percentage points, from 56.0 to 49.6), and the ratio between the share of total equivalized income accumulated by the richest $10 \%$ and the poorest $40 \%$ decreased from 5.0 to 3.7. Meanwhile, the Gini index grew nearly continuously in the U.S., increasing from 38.8 in 1983 to 44.8 in 2013 (an increase of 15\%), and the ratio between the share of the total equivalized income accumulated by the richest $10 \%$ and the poorest $40 \%$ in the country increased from 2.7 to 3.2 .

To a great extent, these divergent trends reflect the particular dynamics of labor incomes observed in each country. Figure 1 shows the accumulated variation in equivalized income (where the index in $1983=100$ ) of the richest $10 \%$ and the poorest $40 \%$, disaggregated into two main sources: labor and other sources (including pension, investment, rent, social benefits, and cash transfer programs). The trends highlight how labor income grew fastest for both the poorest in Brazil and for the richest in the U.S. Between 1983 and 2013, the average equivalized income from labor (labor income) nearly doubled for the poorest $40 \%$ in Brazil ( $87 \%$ growth), and increased only $51 \%$ for the richest $10 \%$ in the country. However, in the U.S., labor income increased $60 \%$ for the richest $10 \%$ and only $2 \%$ for the poorest $40 \%$.

The accumulated variation in average equivalized income from other sources of income for the poorest $40 \%$ in Brazil is represented by a secondary vertical axis (in red) to stress its singular dynamics. Between 1983 and 2013, this source of income grew nearly five-fold. This growth is strictly related to the expansion of cash transfer programs (mainly Bolsa Família) and other important social benefits (such as rural pension and Benefício de Prestação Continuada (BPC), a benefit for the elderly and other vulnerable groups with low per capita income). These programs clearly contributed to increasing the average value of the bottom of the income distribution and to reducing income inequality in Brazil (MAIA, 2013).

In the U.S., the subprime mortgage crisis in 2007 particularly affected the labor income of the poorest, many of whom lost their jobs. However, the fall of other sources 
of income more greatly affected the richest, who have more income in terms of interest and dividends. Between 2007 and 2013, the equivalized income from other sources of the richest $10 \%$ fell by $29 \%$ and the labor income of the poorest $40 \%$ fell by $17 \%$. Other sources of income for the richest were also particularly affected by the dotcom crisis in the 2000s, falling 30\% between 2000 and 2003 .

\section{Figure 1 - Accumulated variation in average equivalized income from labor and other sources for the richest $10 \%$ and poorest $40 \%$, Brazil and the U.S., 1983/2013}
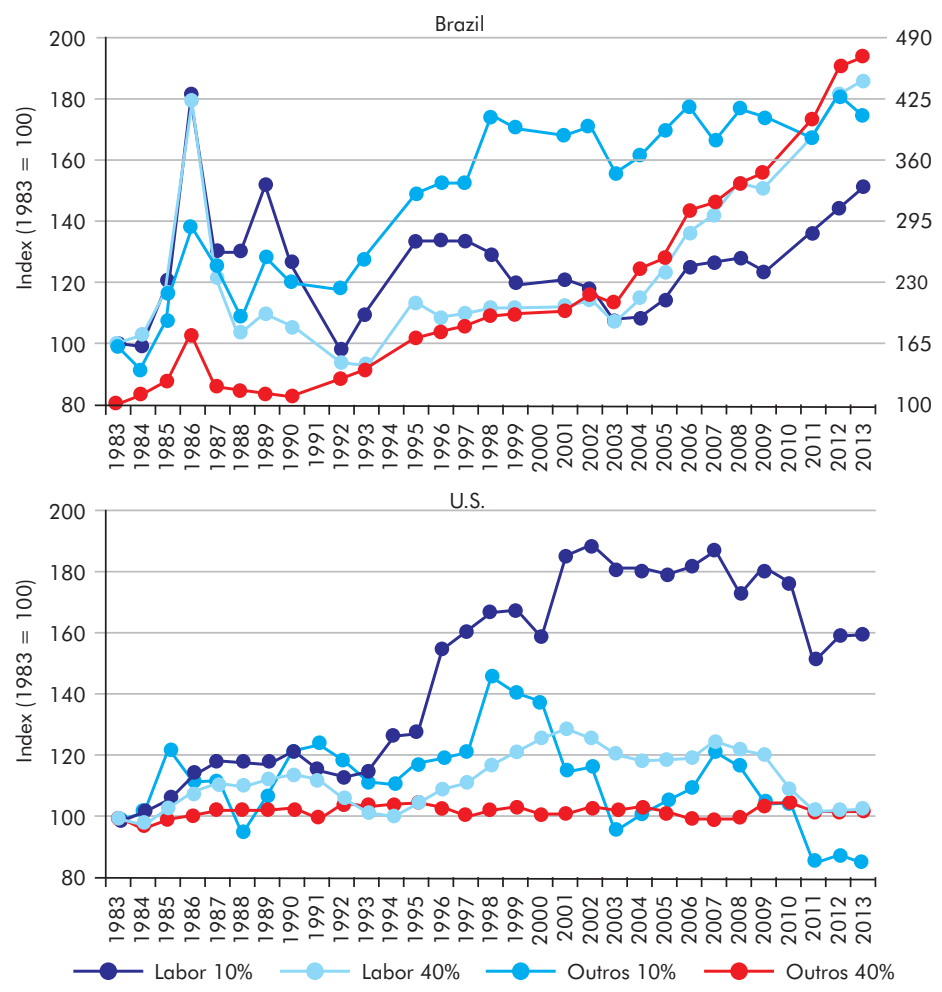

Note: index, $1983=100$.

Source: Authors' elaboration based on data from PNAD (IBGE) and CPS (BLS).

In 2000, benefitting from a singular period of economic growth in developing economies, Brazil's labor income grew substantially for the richest and increased, in particular, for the poorest. For the whole period, the accumulated growth of labor income of the poorest $40 \%$ was 35 percentage points higher than that of the richest 10\% (86\% compared to 51\%, respectively, between 1983 and 2013). Minimum wage also played an important role in this dynamic. Following successive losses in the 1980s, the minimum wage more than doubled between 1995 and 2013, in turn driving growth 
in labor income of those in the lower bound of the income distribution (SABOIA and HALLAK NETO, 2018).

Labor income represents the highest share of total household income and plays a fundamental role in the dynamics of overall income inequality. While, driven by increasing social benefits, the share of other sources in total income grew substantially among the poorest and middle-income segments in Brazil, labor remains a predominant source of income for all income groups (Row \%, in Table 2). In 2013, labor income represented 79\% of the total household equivalized income in Brazil ( $86 \%$ in 1983). Among the poorest, its contribution fell by 16 percentage points, from $86 \%$ in 1983 to $70 \%$ in 2013 . In turn, the participation of labor income grew slightly in the U.S., from $80 \%$ in 1983 to $83 \%$ in 2013, driven by the substantial gains of the richest $10 \%$. Among the richest $1 \%$, the share of labor income increased by 23 percentage points during the period.

Table 2 - The share of labor and other sources of income among groups of equivalized income, and Gini concentration ratio for specific income sources, Brazil and the U.S., 1983/2013

\begin{tabular}{|c|c|c|c|c|c|c|c|c|}
\hline \multirow{3}{*}{$\begin{array}{l}\text { Strata of } \\
\text { Equivalized } \\
\text { Income of }\end{array}$} & \multicolumn{4}{|c|}{ Brazil } & \multicolumn{4}{|c|}{ US } \\
\hline & \multicolumn{2}{|c|}{1983} & \multicolumn{2}{|c|}{2013} & \multicolumn{2}{|c|}{1983} & \multicolumn{2}{|c|}{2013} \\
\hline & Labor & Other & Labor & Other & Labor & Other & Labor & Other \\
\hline \multicolumn{9}{|l|}{ \% Row } \\
\hline Poorest $40 \%$ & 85.6 & 14.4 & 70.2 & 29.8 & 65.1 & 34.9 & 65.0 & 35.0 \\
\hline $50 \%$ & 87.7 & 12.3 & 78.5 & 21.5 & 83.8 & 16.2 & 83.5 & 16.5 \\
\hline $9 \%$ & 84.9 & 15.1 & 81.4 & 18.6 & 82.3 & 17.7 & 86.4 & 13.6 \\
\hline Richest1\% & 82.2 & 17.8 & 83.8 & 16.2 & 70.7 & 29.3 & 93.7 & 6.3 \\
\hline Total & 86.0 & 14.0 & 78.8 & 21.2 & 79.9 & 20.1 & 82.6 & 17.4 \\
\hline \multicolumn{9}{|l|}{$\%$ Column } \\
\hline Poorest $40 \%$ & 9.4 & 9.7 & 11.1 & 17.6 & 12.8 & 27.3 & 10.4 & 26.5 \\
\hline $50 \%$ & 47.8 & 41.1 & 48.3 & 49.4 & 59.8 & 45.8 & 55.2 & 51.9 \\
\hline $9 \%$ & 32.0 & 34.9 & 29.5 & 25.0 & 22.9 & 19.5 & 25.0 & 18.6 \\
\hline Richest1\% & 10.8 & 14.3 & 11.2 & 8.0 & 4.4 & 7.3 & 9.4 & 3.0 \\
\hline Total & 100.0 & 100.0 & 100.0 & 100.0 & 100.0 & 100.0 & 100.0 & 100.0 \\
\hline Gini CR (\%) & 55.4 & 59.4 & 52.4 & 38.9 & 40.0 & 17.5 & 49.2 & 23.9 \\
\hline
\end{tabular}

Source: Authors' elaboration based on data from PNAD (IBGE) and CPS (BLS).

The distribution of labor and other sources of income among the strata of equivalized income (Table 2) allows us to analyze the contribution of each source to overall income inequality. In 2013, the accumulation of labor income among the richest (e.g., 41\% in Brazil and 34\% in the U.S., among the richest 10\%) was higher 
than that from other sources (33\% in Brazil and 22\% in the U.S., among the richest $10 \%)$. Specifically, labor income contributed to increasing overall earnings inequality in both countries in 2013. However, the scenario in Brazil was vastly different in 1983, when income from other sources was more concentrated than labor income (where $49 \%$ came from other sources and $43 \%$ was labor income, among the richest $10 \%$ ).

We must highlight that social benefits and pensions tend to prevail in self-reported income from other sources in both countries. ${ }^{5}$ Clearly, a more precise analysis would allow us to identify how different sources of non-labor income contribute to increasing or decreasing inequality, since the distribution of rents and dividends tends to differ substantially from the distribution of social benefits, and issues can exist related to under-reporting in household surveys.

The Gini concentration ratio ( $C$, Equation 3$)$ indicates the specific concentration of each income source, measuring the extent to which labor income is more concentrated than other sources. Specifically, in Brazil the $C$ for labor income was 35\% higher than the $C$ for other sources (or 14 percentage points higher, with 52.4 from labor income versus 38.9 from other sources in 2013). Meanwhile, in the U.S., the $C$ for labor income was two times higher than the $C$ for other sources during the same year (or 25 percentage points higher, 49.2 from labor income versus 23.9 from other sources). The reduction in the concentration ratio for income from other sources in Brazil was also remarkable - 35\% or 20.5 percentage points, from 59.4 in 1983 to 38.9 in 2013 - and mainly due to the expansion of social benefits among the poorest, such as Bolsa Família and rural pensions.

Based on the changes in the composition of sources of income and in their respective concentration ratios, we can break down the difference in the total Gini index into two main components (Equation 10): (i) the composition effect, the difference due to changes in the composition of sources of income; and (ii) the inequality effect, the difference due to changes in the concentration ratio of each source of income. In both countries, the most substantial contribution to the total difference in the Gini index between 1983 and 2013 was attributed to changes in the concentration ratios (inequality effect) (Table 3). Furthermore, the distribution of labor income played an important role in these dynamics. In Brazil, the reduction in the concentration ratio of labor income contributed

5 In the U.S., social benefits (such as unemployment compensation, worker's compensation, social security payments, supplemental security, public assistance or welfare, veterans benefits, survivor's income, and disability) represented $68 \%$ of the other sources of income in 2011, and pensions (retirement income) represented 14\%. In Brazil, where no clear distinction exists for certain sources of incomes in household surveys (such as cash transfer programs, rural pensions, and BPC), income from all types of pensions and donations (mostly social benefits) represented close to $86 \%$ of the other sources of income in 2013. 
2.46 percentage points to reducing total inequality (38\% of the total reduction of 6.40 percentage points in the Gini index). In the U.S., the rising concentration ratio of labor income contributed 7.42 percentage points to increasing inequality $(80.2 \%$ of the total growth of 9.26 percentage points in the Gini index).

Table 3 - Decomposition of the Gini index into changes in the composition effect and the inequality effect, Brazil and the U.S., 1992-2012

\begin{tabular}{|c|c|c|c|c|c|c|}
\hline & \multicolumn{3}{|c|}{ Brazil } & \multicolumn{3}{|c|}{ U.S. } \\
\hline & Composition & Inequality & Total & Composition & Inequality & Total \\
\hline \multicolumn{7}{|c|}{ Absolute Contribution (p.p.) } \\
\hline Labor & -0.08 & -2.46 & -2.54 & 0.08 & 7.42 & 7.50 \\
\hline Other & -0.26 & -3.60 & -3.86 & 0.57 & 1.19 & 1.76 \\
\hline Total & -0.34 & -6.06 & -6.40 & 0.65 & 8.61 & 9.26 \\
\hline \multicolumn{7}{|c|}{ Relative Contribution (\%) } \\
\hline Labor & 1.3 & 38.4 & 39.7 & 0.8 & 80.2 & 81.0 \\
\hline Other & 4.1 & 56.2 & 60.3 & 6.2 & 12.8 & 19.0 \\
\hline Total & 5.4 & 94.6 & 100.0 & 7.0 & 93.0 & 100.0 \\
\hline
\end{tabular}

Source: Authors' elaboration based on data from PNAD (IBGE) and CPS (BLS).

Other sources of income were especially relevant for the dynamic of inequality in Brazil. The rising share of other sources of income accumulated by the poorest (inequality effect) contributed 3.6 percentage points (56\%) to reducing inequality in Brazil. The overall impact of other sources of income on Gini variation was higher yet (60\%), due to the positive contribution of their composition effect (4\%).

Despite the notable dynamics of other sources, labor income remained the main source of income inequality and has proven to be particularly relevant in explaining changes in the variation of inequality in both countries. However, a more accurate analysis of the composition and inequality effects could be achieved by disaggregating these two sources of income. Next, we focus on explaining the changes in labor income and explaining how these changes affected social groups.

\subsection{OCCUPATIONAL STRUCTURE AND EARNING INEQUALITY}

Occupational structure is certainly one of the main factors explaining income differentials between both Brazil and the U.S., and between various social groups within these countries. The occupational structure in the U.S. reflects a more developed 
economy with more skilled employment such as professionals and specialists. In fact, these two groups represented $44 \%$ of the occupations in the U.S. in 2013, while in Brazil they accounted for only $27 \%$ of occupations (Table 4 ). The low prevalence of occupations characteristic of middle-income groups in Brazil tends to generate low levels of average earnings and a concentration of people in the lower segment of the income distribution. Larger groups of low-income households at the bottom of the distribution may inhibit educational expansion and reduce intergenerational social mobility (SAKAMOTO et al., 2014).

Despite some improvements, the occupational structure in Brazil is still characterized by large proportions of routinized and low-paid service occupations. A more detailed picture of these groups (Table 4) shows that the most representative (two-digit) occupations in 2013 were those related to sales (12.2\% in 2013), building maintenance and cleaning $(9.0 \%)$, construction and extraction $(8.7 \%)$, and agricultural work $(8.3 \%$ in 2013) - occupations that had average monthly earnings below US\$ 800 in 2013. Overall, farming, low-paid services, sales, and labor were responsible for $65 \%$ of Brazilian occupations in 2013 (74\% in 1983), and only 38\% in the U.S. during the same year (46\% in 1983). In turn, skilled occupations, which usually require higher education degrees and are better paid, and include such jobs related to biological and health, mathematics and related, and social and human sciences occupations, represented more than $15 \%$ of the occupations in the U.S. in 2013, while they accounted for only $4 \%$ in Brazil.

In addition to significant differences between average earnings in Brazil and the U.S., other aspects of the occupational structure are also notable. In 2013, the ratio of average monthly earnings in the U.S. over those in Brazil was 4.1 (US\$ 4,042 versus US\$ 998, respectively), but this ratio differs significantly among occupational groups. The ratio between top occupational groups is lower. For example, the average monthly earnings of sales and laborers were 4.1 times higher in the U.S. (US\$ 3,204 versus US\$ 790 in 2013), 2.8 times higher in the U.S. for professionals (USS\$ 5,817 versus US\$ 2,103 ), and 2.3 times higher in the U.S. for management occupations (US\$ 5,733 versus US\$2,483). Among two-digit occupational groups, the ratio is higher for construction and extraction workers (4.6) and lower for mathematics and related occupations (1.9).

As labor rewards for low-skilled social groups are relatively lower in Brazil than in the U.S., income differences between occupational groups in Brazil tend to be higher. For example, in 2013, the average monthly earnings of professionals in Brazil were 2.7 times higher than that of sales and laborers (1.8 times higher for the same comparison in the U.S.), and the earnings of professionals were 4.1 times higher than those of farming in Brazil (3.8 times higher for the same comparison in the U.S.). Specifically, inequality between occupational groups is higher in Brazil mainly due to the more extreme conditions of remuneration that workers are submitted to in the lowest occupational groups, compared to their U.S. counterparts. 
Table 4 - Percentage and average monthly earnings of the employed population with positive earnings, according to two-digit occupational groups, Brazil and the U.S., 1983/2013

\begin{tabular}{|c|c|c|c|c|c|c|c|c|}
\hline \multirow{3}{*}{ Occupational Structure } & \multicolumn{4}{|c|}{ Population } & \multicolumn{4}{|c|}{ Earnings } \\
\hline & \multicolumn{2}{|c|}{ Brazil } & \multicolumn{2}{|c|}{ U.S. } & \multicolumn{2}{|c|}{ Brazil } & \multicolumn{2}{|c|}{ U.S. } \\
\hline & $\begin{array}{l}2013 \\
(\%)\end{array}$ & $\begin{array}{l}\text { 13-83 } \\
\text { (p.p.) }\end{array}$ & $\begin{array}{c}2013 \\
(\%)\end{array}$ & $\begin{array}{l}\text { 13-83 } \\
\text { (p.p.) }\end{array}$ & $\begin{array}{c}2013 \\
\text { (USD) }\end{array}$ & $\begin{array}{c}13 / 83 \\
(\%)\end{array}$ & $\begin{array}{c}2013 \\
\text { (USD) }\end{array}$ & $\begin{array}{c}13 / 83 \\
(\%)\end{array}$ \\
\hline Management Occupations & 7.1 & 0.5 & 18.4 & 3.0 & 2,483 & 6 & 5,733 & 22 \\
\hline Professionals & 9.7 & 4.3 & 22.8 & 7.2 & 2,103 & 34 & 5,817 & 31 \\
\hline Legal & 0.8 & 0.5 & 1.2 & 0.4 & 3,591 & 5 & 10,345 & 51 \\
\hline Biological and health & 1.4 & 0.9 & 4.1 & 1.1 & 2,945 & 18 & 7,424 & 45 \\
\hline Math and related & 1.1 & 0.6 & 5.0 & 2.3 & 3,527 & -6 & 6,740 & 15 \\
\hline Social and human sciences & 1.5 & 0.8 & 6.2 & 2.4 & 2,361 & 5 & 5,364 & 29 \\
\hline Education and library & 4.9 & 1.6 & 6.2 & 1.0 & 1,232 & 55 & 3,565 & 15 \\
\hline Specialists & 17.8 & 3.6 & 21.0 & -1.8 & 991 & 16 & 3,095 & 16 \\
\hline Entertainment and related & 1.5 & 0.9 & 2.4 & 0.5 & 1,043 & -10 & 4,071 & 20 \\
\hline Technicians & 3.2 & 0.9 & 4.9 & 1.0 & 1,138 & 0 & 2,965 & 0 \\
\hline Clerks & 7.6 & -0.3 & 8.4 & -4.8 & 995 & 24 & 2,893 & 21 \\
\hline Protective services & 3.0 & 0.7 & 2.1 & 0.6 & 1,065 & 71 & 4,127 & 26 \\
\hline Customer services & 2.4 & 1.5 & 3.2 & 0.9 & 654 & -31 & 2,447 & -13 \\
\hline Sales and laborers & 38.0 & -0.6 & 25.5 & -8.5 & 790 & 39 & 3,204 & 8 \\
\hline Sales & 12.2 & 3.5 & 7.4 & -1.1 & 788 & 13 & 3,352 & 19 \\
\hline Installation and repair & 2.7 & 1.0 & 3.0 & -0.9 & 881 & 16 & 3,708 & -2 \\
\hline Construction and extraction & 8.7 & -1.1 & 4.3 & -0.3 & 716 & 104 & 3,259 & 4 \\
\hline Production & 8.1 & -5.4 & 5.1 & -5.6 & 730 & 38 & 3,063 & 7 \\
\hline Transportation and moving & 6.2 & 1.4 & 5.6 & -0.6 & 934 & 15 & 2,825 & 1 \\
\hline Low-paid services & 19.2 & 3.0 & 11.7 & 0.6 & 513 & 57 & 1,544 & 17 \\
\hline Personal care and related & 6.1 & 1.4 & 3.4 & 1.1 & 573 & 32 & 1,725 & 25 \\
\hline Food and serving-related & 4.1 & 1.6 & 4.9 & 0.0 & 588 & 25 & 1,273 & 7 \\
\hline $\begin{array}{l}\text { Building maintenance and } \\
\text { cleaning }\end{array}$ & 9.0 & 0.0 & 3.4 & -0.5 & 437 & 92 & 1,755 & 22 \\
\hline Farming & 8.3 & -10.8 & 0.6 & -0.6 & 522 & 61 & 2,282 & 57 \\
\hline Total & 100.0 & 0.0 & 100.0 & 0.0 & 998 & 44 & 4,042 & 26 \\
\hline
\end{tabular}

Source: Authors' elaboration based on data from PNAD (IBGE) and CPS (BLS).

Despite the substantial reduction in the gap between Brazil and the U.S., earnings inequality continues to be higher in Brazil. In 2013, the Gini index in Brazil (48.6) was $2.4 \%$ higher (or 1.2 percentage points) than that in the U.S. (47.4), and the Theil index 
was $13.7 \%$ higher (or 6.1 points) in Brazil (50.7) compared to the U.S. (44.6). ${ }^{6}$ The share of occupational groups at the bottom of the income distribution is lower in the U.S. and their average earnings are relatively higher than in Brazil. As a result, the total earnings accumulated in the lower bound of the earnings distribution is higher in the U.S. than in Brazil.

Another notable result is the difference of the Theil index for inequality between the 20 two-digit occupational groups (Equations 13 and 14). The index is substantially higher in Brazil, both in absolute value and as a percentage of total inequality. In 2013, inequality between occupational groups explained 17 points of the total inequality (34\% of the total) in Brazil, and only 9 points in the U.S. (21\%) (Figure 2). As a result, the Theil index for within-group inequality was nearly the same in both countries in 2013 (34 and 35 points in Brazil and the U.S., respectively). Specifically, differences in the patterns of earnings inequality of these countries were essentially due to inequality between occupational groups.

After 30 years, patterns of earnings inequity in Brazil and the U.S. converged substantially. After a long period of instability in the 1980s and mid-1990s, which was characterized by low economic growth and hyperinflation in Brazil, the Gini index in the country decreased by 14\% between 1983 and 2013 (or 8 percentage points, from 57 to 48 ). In the U.S., it increased by $8 \%$ (or 3 percentage points, from 44 to 47 ). The Theil index demonstrated similar trends, though at different magnitudes. During the same period, the Theil index decreased by $22 \%$ in Brazil (or 14 points, from 65 to 51 ) and increased by $34 \%$ in the U.S. (or 12 points, from 33 to 45 ).

Average earnings increased faster from 1983 to 2013 for occupational groups at the bottom of the income distribution in Brazil. For example, average hourly earnings grew $61 \%$ during the period for farming, 57\% for low-paid services, and 39\% for sales and laborers. The growth was of $6 \%$ for managers, $34 \%$ for professionals and $16 \%$ for specialists. Wages for the groups at the bottom of the income distribution in Brazil were largely influenced by the minimum wage, which, as previously noted, grew substantially during this period. Moreover, the share of employees benefitting from labor regulations also increased quickly during the period, contributing to an improvement in overall average earnings. ${ }^{7}$

6 Differences between Gini and Theil index values may be due to: (i) measurement scale, since the Gini index varies between 0 and $1-1 / n$ while the Theil ranges from 1 to $\ln n$; and (ii) sensitivity, as the Gini index is relatively more sensitive to intervals with higher frequency densities, which are generally found in the middle of the income distribution.

7 For example, the percentage of informal employees and self-employed workers in Brazil decreased from $53 \%$, in 1983 , to $41 \%$, in 2013 . 
Figure 2 - Gini and Theil T indices for earnings inequality within (Theil Within) and between (Theil Between) occupations (two-digit), employed population with positive earnings, Brazil and the U.S., 1983/2013
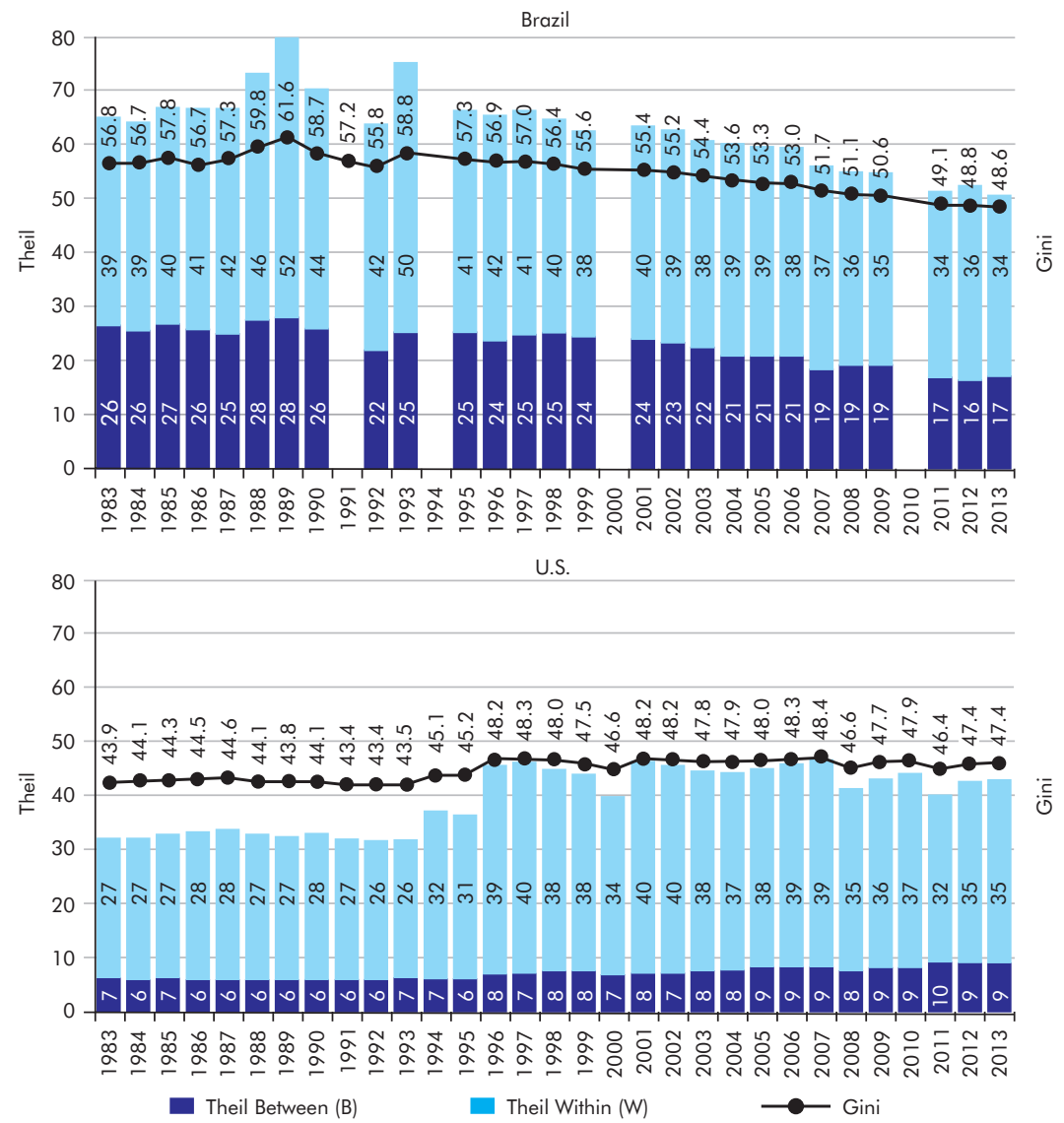

Source: Authors' elaboration based on data from PNAD (IBGE) and CPS (BLS).

In the U.S., the $26 \%$ growth in average earnings between 1983 and 2013 was largely influenced by the dynamics among professionals (variation of $31 \%$ ), and to a lesser extent, managers (22\%). Agricultural workers witnessed a substantial increase in earnings (57\%), albeit not highly relevant with respect to the U.S. occupational structure, as they accounted for less than 1\% of occupations in 2013. Average earnings increased at a slower pace for routinized sales and laborers (8\%), intermediate specialists (16\%), and low services workers (17\%).

Based on such changes in the structure of occupational groups and patterns of inequality within each group, we can decompose the variation in the Theil $\mathrm{T}$ index between 1983 and 2013 into two main sources (Equations 15 and 16): (i) differences 
between occupational groups (between effect); and (ii) differences within occupational groups (within effect). The results in Table 6 highlight that the most notable contribution to reducing inequality in Brazil was given by changes in the differences between occupational groups (9.3 points, or $65 \%$ of the total reduction of 14.4 points). Average wages for most occupational groups are now closer to the national average, and the share of workers in middle occupational groups are higher than they were 30 years ago.

The only exception is the positive between effect of professionals, which contributed 5 points to increasing inequality. The share of income accumulated by professionals only increased during the period due an increase in this group's share of the total workforce (4 points between 1983 and 2013), since the average earnings of professionals grew more slowly than the national average. In turn, the accumulation of earnings by managers decreased due to both slower growth in their average earnings, and a decrease in the share of workers in this group. As a result, managers contributed more than 11 points to reducing inequality between occupational groups in Brazil.

In the U.S., the growth in earnings inequality was due mainly to the dynamics of the top occupational groups, professionals and managers. Professionals contributed 12 points to increasing the Theil index, primarily due to the faster growth of average earnings in this group (which were $44 \%$ higher than the national average in 2013), in addition to the increasing inequality within this group. For example, average monthly earnings grew more than $45 \%$ for Legal-, and Biological-, and Health-related occupations, which are the two groups with the highest average wages in the occupational structure. As a result, they contributed 4 points to increasing between effect inequality and 3 points to increasing within effect inequality. While the average earnings of managers increased at nearly the same pace as the national average (22\% and $26 \%$, respectively), inequality within the managers group grew significantly, and contributed 4 percentage points to increasing the Theil index.

The substantial growth in average earnings among low-paid services occupations, the group of the bottom of the occupational structure, contributed to reducing inequality in Brazil. In the U.S., low-paid services also contributed to reducing the Theil index, mainly due to the decrease in the within effect inequality of this group. Average earnings also increased for the most vulnerable occupational group, farming. However, this growth was offset by the substantial reduction in the share of farming in the workforce. As a result, farming contributed to increasing inequality in both countries.

The average earnings of specialists are close to the national average. Thus, the higher the share of this group in the occupational structure, the lower the levels of between inequality. The share of this group is still growing in Brazil (increasing 4 percentage points between 1983 and 2013), which in turn has played an important role in reducing between inequality (4 points). Finally, sales and laborers also made an important 
contribution to reducing inequality in Brazil and the U.S., particularly since earnings are more equality distributed among production workers in both countries. The share of sales workers in Brazil increased in the period (3.5 percentage points), for whom average earnings are closer to the national average. In the U.S., the share of occupations with low, average wages (such as installation and repair and transportation and moving) declined.

Table 5 - Percentage variation in Theil T during the period 1983-2013 due to inequality between and within occupational groups, Brazil and the U.S.

\begin{tabular}{|c|c|c|c|c|c|c|}
\hline & \multicolumn{3}{|c|}{ Brazil } & \multicolumn{3}{|c|}{ U.S. } \\
\hline & Between & Within & Total & Between & Within & Total \\
\hline Management Occupations & -11.3 & -0.9 & -12.2 & 0.4 & 3.6 & 4.0 \\
\hline Professionals & 4.7 & 2.7 & 7.4 & 5.7 & 6.2 & 12.0 \\
\hline Legal & 1.5 & 0.7 & 2.2 & 1.7 & 1.3 & 3.0 \\
\hline Biological and health & 1.9 & 0.9 & 2.8 & 2.3 & 1.5 & 3.8 \\
\hline Math and related & 0.1 & 0.3 & 0.4 & 1.2 & 1.1 & 2.3 \\
\hline Social and human sciences & 0.5 & 0.8 & 1.3 & 1.0 & 1.8 & 2.8 \\
\hline Education and library & 0.7 & 0.0 & 0.7 & -0.5 & 0.6 & 0.0 \\
\hline Specialists & -3.8 & -0.3 & -4.1 & -0.8 & 0.3 & -0.5 \\
\hline Entertainment and related & -0.5 & 0.4 & -0.1 & -0.1 & 0.6 & 0.5 \\
\hline Technicians & -1.4 & -0.3 & -1.7 & -0.8 & 0.1 & -0.7 \\
\hline Clerks & -1.3 & -0.6 & -1.9 & 0.8 & -0.5 & 0.4 \\
\hline Protective services & 0.4 & 0.3 & 0.8 & 0.0 & 0.1 & 0.2 \\
\hline Customer service & -1.0 & -0.2 & -1.2 & -0.7 & -0.1 & -0.8 \\
\hline Sales and laborers & -1.7 & -3.8 & -5.5 & -2.5 & -0.9 & -3.4 \\
\hline Sales & -2.3 & -0.6 & -2.9 & -0.2 & 0.6 & 0.4 \\
\hline Installation and repair & -0.5 & 0.0 & -0.4 & -1.0 & -0.2 & -1.2 \\
\hline Construction and extraction & 1.3 & -0.7 & 0.6 & -0.7 & 0.0 & -0.7 \\
\hline Production & 0.9 & -2.2 & -1.3 & 0.0 & -0.9 & -0.9 \\
\hline Transportation and moving & -1.2 & -0.3 & -1.5 & -0.7 & -0.3 & -1.0 \\
\hline Low services & -1.1 & -1.3 & -2.4 & -0.2 & -0.6 & -0.8 \\
\hline Personal care and other & -0.6 & -1.0 & -1.6 & -0.4 & 0.1 & -0.3 \\
\hline Food and serving related & -0.6 & -0.1 & -0.7 & 0.0 & -0.3 & -0.3 \\
\hline $\begin{array}{l}\text { Building maintenance and } \\
\text { cleaning }\end{array}$ & 0.0 & -0.2 & -0.1 & 0.2 & -0.4 & -0.2 \\
\hline Farming & 4.0 & -1.7 & 2.3 & 0.2 & -0.1 & 0.1 \\
\hline Total & -9.3 & -5.1 & -14.4 & 2.8 & 8.6 & 11.4 \\
\hline
\end{tabular}

Source: Authors' elaboration based on data from PNAD (IBGE) and CPS (BLS). 


\subsection{OCCUPATIONAL STRUCTURE AND SOCIAL INEQUALITIES}

Some of the differences between occupational groups may be related to other types of social inequalities. For example, a portion of the earnings differences between professionals and low-paid services groups may be related to differences in the level of educational attainment and the age of their respective workers. Similarly, earnings inequalities would also reflect certain types of segregation, discrimination, and/or other unmeasured factors that may be, for example, associated with race, gender, and occupational structure.

Table 6 presents the main social differences between the Brazilian and U.S. employed populations with positive earnings. Results highlight the vast differences between levels of educational attainment. In 2013, only 15\% of the labor force with positive earnings in Brazil held a higher education diploma (versus 35\% in the U.S.), and only 52\% in Brazil held a secondary school diploma or higher (versus 93\% in the U.S.). The U.S. population is also older due to its more advanced stage of demographic transition. In 2013, 58\% of the U.S. workers were 40 years or older versus $44 \%$ in Brazil.

While the share of black workers in the workforce is similar in both countries $(9 \%$ in Brazil and 11\% in the U.S. in 2013), Brazil is characterized by its high share of other races (43\% in 2013). This group includes Asians, indigenous, and Pardo (the descendants of interracial marriages between white, black, and/or indigenous persons). The share of the female labor force is still growing in Brazil, although it was six percentage points lower than in the U.S. in 2013.

Most social groups are also subjected to higher levels of earnings inequality in Brazil. For example, in 2013, the average monthly earnings of those with a higher education diploma in Brazil were 3.8 times higher than that of those with a completed primary school education or less. In the U.S., those with a higher education diploma on average earned 3.1 times more than those who only completed primary school. In 2013, the average monthly earnings of white workers in Brazil were $69 \%$ higher than those of black workers in the country. In the U.S., white workers earned $40 \%$ more than black workers during the same year.

Meanwhile, the earning differentials between gender and age were substantially higher in the U.S. In 2013, men's average monthly earnings in the country was 50\% higher than women's. Meanwhile in Brazil, men earned 37\% more than women during the same year. Differences in levels of educational attainment between men and women may partially explain such differences, which are relatively more pronounced and in favor of women in Brazil..$^{8}$ More stringent labor regulations may also play an

\footnotetext{
8 For example, in 2013 the percentage of the employed population with positive earnings and a secondary diploma or higher was 16 percentage points higher for women in Brazil (62\% for women and $46 \%$ for men), and only 3 percentage points higher for women in the U.S. ( $93 \%$ for women and $90 \%$ for men).
} 
important role in curbing gender inequality in Brazil. In turn, the average monthly earnings of adults between the ages of 40 and 49, for example, was 6.9 higher than those of young workers between the ages of 16 and 19 in the U.S., while in Brazil, the average earnings of the former age group were only 2.6 times higher than those of the latter age group. This variation may be related to the higher levels of intra-generational mobility in the U.S.

\section{Table 6 - Percentage distributionand average monthly earnings of the employed population with positive earnings by social characteristics, Brazil and the U.S., 1983/2013}

\begin{tabular}{|c|c|c|c|c|c|c|c|c|}
\hline \multirow{3}{*}{ Social Characteristic } & \multicolumn{4}{|c|}{ Population } & \multicolumn{4}{|c|}{ Earnings } \\
\hline & \multicolumn{2}{|c|}{ Brazil } & \multicolumn{2}{|c|}{ U.S. } & \multicolumn{2}{|c|}{ Brazil } & \multicolumn{2}{|c|}{ U.S. } \\
\hline & $\begin{array}{c}2013 \\
(\%)\end{array}$ & $\begin{array}{l}\text { 13-83 } \\
\text { (p.p.) }\end{array}$ & $\begin{array}{c}2013 \\
(\%)\end{array}$ & $\begin{array}{l}\text { 13-83 } \\
\text { (p.p.) }\end{array}$ & $\begin{array}{c}2013 \\
\text { (USD) }\end{array}$ & $\begin{array}{c}13 / 83 \\
(\%)\end{array}$ & $\begin{array}{c}2013 \\
\text { (USD) }\end{array}$ & $\begin{array}{c}13 / 83 \\
(\%)\end{array}$ \\
\hline \multicolumn{9}{|l|}{ Education } \\
\hline Primary school or less & 40.3 & -38.5 & 2.8 & -2.8 & 633 & 28.6 & 1,949 & -9.4 \\
\hline Unfinished secondary school & 7.8 & 3.4 & 4.6 & -8.0 & 615 & -4.3 & 1,771 & -13.0 \\
\hline Secondary school diploma & 37.2 & 25.1 & 57.2 & -2.2 & 921 & -24.2 & 3,045 & 4.0 \\
\hline Higher education diploma & 14.7 & 10.0 & 35.4 & 12.9 & 2,396 & -14.9 & 6,112 & 26.8 \\
\hline \multicolumn{9}{|l|}{ Age } \\
\hline $16-19$ & 5.2 & -6.1 & 2.6 & -3.1 & 425 & 76.7 & 685 & 2.5 \\
\hline $20-29$ & 23.7 & -7.9 & 20.1 & -9.7 & 739 & 31.1 & 2,380 & -1.0 \\
\hline $30-39$ & 27.0 & 2.0 & 22.0 & -5.5 & 1,048 & 18.3 & 4,096 & 12.3 \\
\hline $40-49$ & 22.6 & 5.5 & 23.3 & 4.0 & 1,125 & 25.7 & 4,724 & 19.2 \\
\hline $50-59$ & 15.2 & 5.0 & 22.6 & 7.0 & 1,222 & 50.8 & 4,922 & 24.7 \\
\hline $60+$ & 6.3 & 1.5 & 12.2 & 4.3 & 1,231 & 82.7 & 4,457 & 44.2 \\
\hline \multicolumn{9}{|l|}{$\operatorname{Race}^{1}$} \\
\hline White & 48.3 & -9.2 & 68.6 & -19.8 & 1,258 & -13.0 & 4,424 & 33.5 \\
\hline Black & 9.0 & 2.3 & 11.2 & 1.6 & 741 & 24.9 & 3,155 & 27.8 \\
\hline Other & 42.7 & 7.0 & 23.1 & 15.1 & 757 & -5.5 & 3,335 & 20.3 \\
\hline \multicolumn{9}{|l|}{ Gender } \\
\hline Male & 57.8 & -10.8 & 54.3 & -5.2 & 1,127 & 38.2 & 4,797 & 19.0 \\
\hline Female & 42.2 & 10.8 & 48.5 & 2.2 & 821 & 90.5 & 3,196 & 50.5 \\
\hline
\end{tabular}

Note: ${ }^{1}$ Information for race in Brazil refers to 1986.

Source: Authors' elaboration based on data from PNAD (IBGE) and CPS (BLS). 
Differences between social groups followed the same dynamics witnessed for the occupational groups - specifically, a decreasing inequality trend in Brazil and an increasing trend in the U.S. In Brazil, average earnings grew faster for some of the most vulnerable social groups: people with a primary education or less; between the ages of 16 and 19; aged 60 or over; blacks; and females. In the U.S., average earnings grew faster for those with a higher education, those who were 60 or above, white people, and females.

Figure 3 - Theil T for earnings inequality within (Theil Within) and between (Theil Between) occupational (Two-Digit) and social groups, employed population with positive earnings, Brazil and the U.S., 1983/2013
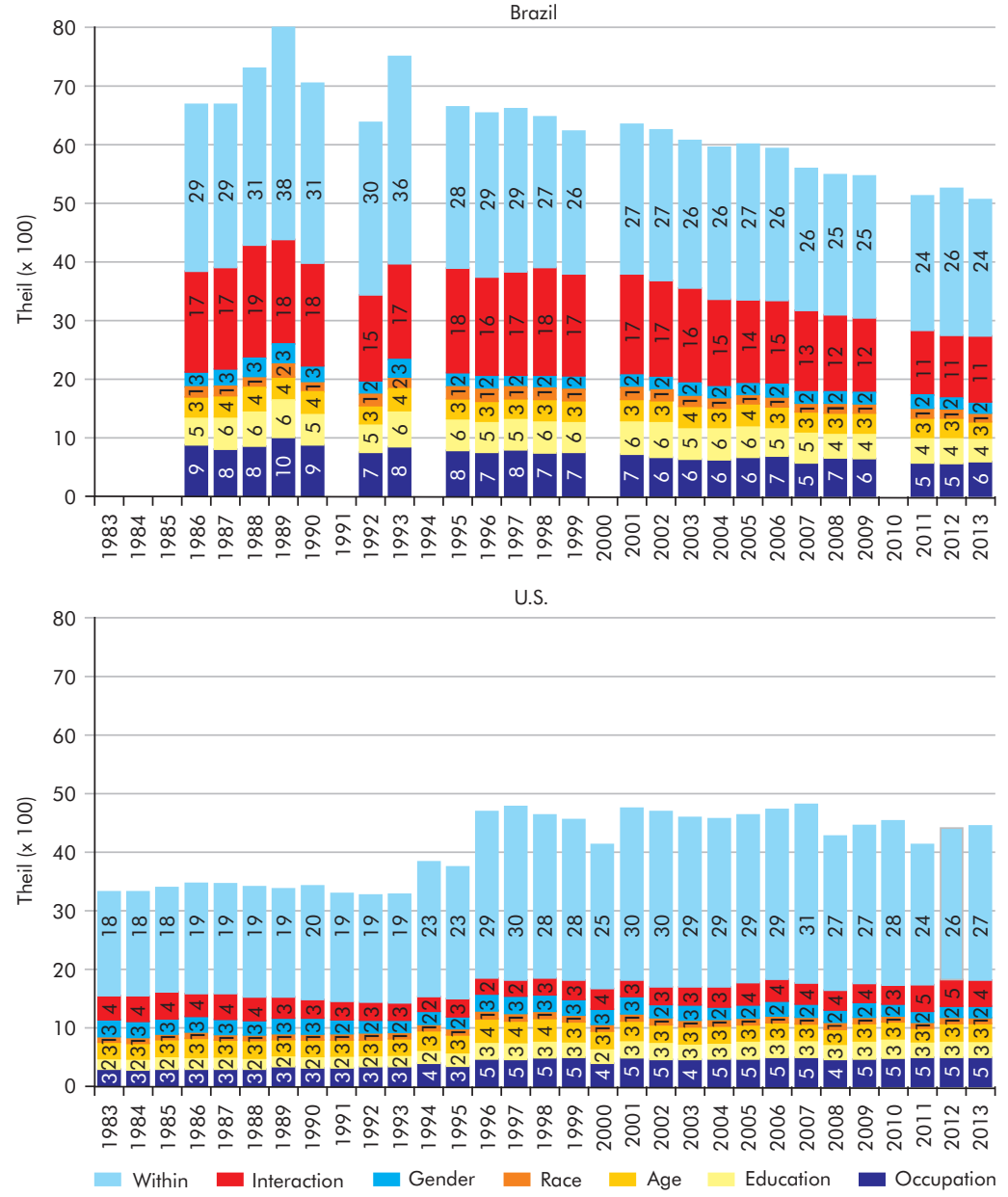

Source: Authors' elaboration based on data from PNAD (IBGE) and CPS (BLS). 
As these social characteristics tend to be interrelated with the occupational structure, we must isolate the independent contribution of each factor in explaining total inequality. Figure 3 presents the marginal contribution of each social characteristic and the occupational structure in explaining the total Theil index (Equation 19). The between inequality now represents the share of the total inequality due to differences among the combinations of groups defined by occupation, education, age, race and gender. The marginal contribution of education, for example, represents the share of between inequality that can be independently explained by differences among the groups of educational attainment, after controlling for differences between other groups. The share of between inequality that cannot be independently explained by only one variable is represented by the interaction effect.

The results highlight that occupational structure remains the primary independent source of between inequality in both countries, with a marginal contribution between 5 (U.S.) and 6 (Brazil) points in 2013. Education and age are the second- and thirdmost relevant independent factors - both variables contributing 6 (U.S.) and 7 (Brazil) points to total inequality. Gender and race together contribute no greater than 3 points to total inequality, in both countries.

The interaction effect is a notable difference between Brazil and the U.S., it is substantially higher in Brazil (11 points in 2013, versus 4 points in the U.S.). This result indicates a stronger relationship between social characteristics and occupational structure in Brazil, which in turn plays an important role in explaining total inequality in the country. After controlling for the differences between social and occupational groups, including the interaction effect, the inequality that remains within these groups is higher in the U.S. This result is particularly evident in the 2000s, when inequality decreased in Brazil but increased sharply in the U.S.

\subsection{DISCUSSION}

Brazil and the U.S. are well known for their high levels of socioeconomic inequality. Brazilian inequality reduced substantially in the early 2000s, but it continues to be extreme and remains greater than in the U.S. The bottom and middle groups in Brazil have very low levels of per capita income, that would be considered extreme poverty by U.S. standards. The concentration of people in the lower portion of the income distribution in Brazil is primarily a result of the country's labor market, which is over represented by low-skilled and low-paid occupational groups. High- and middleincome groups, such as professional, technical, and administrative support occupations, are not as common as in the U.S. 
Salary differences between occupational groups are larger in Brazil, particularly among occupations in the upper and lower bounds of the occupational structure. Brazil is historically known for a labor market structure that is highly segmented (ULYSSEA, 2006). On one hand, a small share of high-skilled workers attains better job opportunities in a more sheltered labor market that is compliant with labor legislation, and is characterized by higher productivity due to a greater application of advanced technology. On the other hand, a large majority of low-skilled workers is concentrated in low-paid services, farming, and other routine manual occupations. They are largely subjected to high levels of competition, extremely poor remuneration, precarious employment security, and lack the social benefits provided by labor legislation.

As noted above, the positive news for Brazilian policymakers is that inequality declined significantly in the 2000s. Social benefits explain some of this drop: per capita income of the poorest benefited from important social policies implemented in the 1990s and 2000s, such as cash transfer programs and the pension system. Moreover, benefitting from the commodity boom and unusual economic growth during this period, the labor market in Brazil produced more jobs and higher wages. The labor income of the poorest groups also grew substantially due to increases in the minimum wage that nearly doubled during this period.

Our findings show that labor income remains the main source of self-reported income in households, and tends to dictate the dynamics of total inequality. In the U.S., the share of labor income in the household is even higher, and the substantial gains of the richest workers have been the primary source of rising inequality since the 1980s. High-skilled professionals and those in management occupations particularly benefited during this period, which may be associated with the emergence of an informational society, skill-biased technological change, and the increased bargaining power of this segment of the labor force (ACEMOGLU and AUTOR, 2010).

Occupational change in the U.S. has been greater for the higher-skilled job sector. Management occupations and professionals were the only occupational groups that increased their share in the U.S. occupational structure. Some workers in these groups particularly benefited by increased earnings, as shown by rising between and within components of inequality. In Brazil, by contrast, economic growth remains more closely related to a decreasing share of farming occupations and an increasing share of middle - and bottom - income occupational groups such as specialists and low-paid services. The overall impact of changes in the occupational structure on total inequality was negative, however, since the average earnings of the latter groups were closer to those of the national average. The average earnings of bottom-income occupational groups also grew faster than the average in Brazil, which also contributed to reducing within-group inequality. 
The most vulnerable occupational groups tend to be most affected during periods of recession, which may eliminate their employment or reduce their relative wages, and consequently increase inequality. For example, the dotcom and sub-prime mortgage crises in the 2000s instigated a series of economic forces that ultimately damaged the labor income of the poorer groups in the U.S. In Brazil, however, the poorer groups were less affected by the international crises because the demand for commodities remained high and the minimum wage played an important role in supporting the bottom-income occupational groups.

Within inequality varies across occupational groups in part due to the characteristics of the workers employed in such occupations. These characteristics include education, age, race, gender, and to a certain extent, region. These variables have direct effects on wages in both Brazil and the U.S. Low-income occupational groups tend to have greater proportions of women, black people, and less-educated workers. These groups may face discrimination and exploitation or they may have lower productivity (SAKAMOTO and KIM, 2014). Nonetheless, occupational structure remains a major source of earnings inequalities in both countries, even after controlling for other characteristics.

\section{CONCLUSIONS}

Earnings inequality is significantly higher in Brazil than in the U.S. Characterized by lesser economic development than the U.S., the Brazilian labor force faces lower levels of education, wages, and occupational skills. While both countries have high levels of inequality, low economic development in Brazil notably reduces the proportion of total income that accrues in the bottom two quintiles of the distribution. Our findings indicate that the distribution of workers across occupational groups is an important factor in explaining the higher level of inequality in Brazil compared to the U.S. Part of the decline in inequality in Brazil in recent decades has been associated with occupational upgrading at the lower end of the occupational structure, while part of the increase in inequality in the U.S. in recent decades has been associated with the slightly higher proportions of managers and professionals employment.

In general, however, our analysis suggests that occupational structure has slightly more systematic effects on income inequality at a lower level of economic development. At the higher level of development in a post-industrial society (i.e., the U.S. in this case), a substantial portion of rising inequality appears to be due to rising withingroup inequality among high-skilled employees, which may be more related to organizational and other skill-related variables unobserved in our data, such as firm 
productivity or market advantage (KIM and SAKAMOTO, 2008). Furthermore, even at a lower level of economic development (i.e., Brazil in this case), within-group inequality plays a significant role and has grown among high-skilled occupations. Increased cash transfer programs and a rising minimum wage have reduced inequality in Brazil in recent decades, and such changes transcend occupational categories.

A limitation of our analysis is that the effects of occupations on total inequality depend on the choice of the typology of occupational stratification. While similar to prior studies (ACEMOGLU and AUTOR, 2010; MAIA and SAKAMOTO, 2015), our strategy was largely limited by the availably of comparable data for the whole period of analysis. Further studies would focus on more recent periods to highlight specific groups of occupations, capturing more precisely the effects of changes in the demand for technology, tasks, and skills in modern labor markets. For example, identifying key occupations in science, technology, engineering, and math that may play a more important role in the dynamics of inequality in the U.S.; and differences within farming occupations that may play a more key role in inequality in Brazil.

\section{REFERENCES}

ACEMOGLU, D.; AUTOR, D. Skills, tasks and technologies: implications for employment and earnings. NBER Working Paper Series, n. 16082, p. 154, 2010.

ACEMOGLU, D.; ROBINSON, J. A. Why nations fail: the origins of power, prosperity, and poverty. [s.l.] Crown Publishers, 2012.

AUTOR, D. H.; LEVY, F.; MURNANE, R. J. The skill content of recent technological chagne: an empirical exploration. Quartertly Journal of Economics, v. 118, n. 4, p. 1279-1333, 2003.

BANERJEE, R. R. Farmers' perception of climate change, impact and adaptation strategies: a case study of four villages in the semi-arid regions of India. Natural Hazards, v. 75, n. 3, p. 2829-2845, feb. 2015.

BELL, D. The coming of post-industrial society: a venture in social forecasting. [s.l.] Basic Books, 1976.

BLAU, P. M.; DUNCAN, O. D. Some preliminary findings on social stratification in the United States. Acta Sociologica, v. 9, n. 1-2, p. 4-24, 1966.

BOURGUIGNON, F.; FERREIRA, F. H. G. Inequality of opportunity in Brazil. Review of Income and Wealth, v. 53, n. 4, p. 585-618, 2007.

BUHMANN, B. et al. Equivalence scales, well-being, inequality, and poverty: sensitivity estimates across ten countries using the Luxembourg Income Study (LIS) database. Review of Income and Wealth, v. 34, n. 2, p. 115-142, 1988.

BURKHAUSER, R. V.; SMEEDING, T. M.; MERZ, J. Relative inequality and poverty in Germany and the United States using alternative equivalence scales. Review of Income and Wealth, v. 42, n. 4, p. 381-400, 1996. 
CASTELLS, M.; AOYAMA, Y. An empirical assessment of the informational society: employment and occupational structures of G-7 countries, 1920-2000. International Labour Review, v. 141, n. 1-2, p. 123-159, 2002.

CAVAlCANTI, T. V.; MAgalhães, A. M.; TAVARES, J. A. Institutions and economic development in Brazil. The Quarterly Review of Economics and Finance, v. 48, n. 2, p. 412432, may 2008.

CRISTINA, E. C. B.; ALMEIDA, E. S. Convergência local de renda no Brasil. Economia Aplicada, v. 16, n. 3, p. 399-420, 2012.

ENGERMAN, S. L.; SOKOLOFF, K. L. Factor endowments, institutions, and differential paths of growth among new world economies: a view from economic historians of the United States. NBER Historical Paper, n. 66, p. 1-45, 1994.

FERREIRA, F. H. G.; GIGNOUX, J. The measurement of inequality of opportunity: Theory and an application to Latin America. Review of Income and Wealth, v. 57, n. 4, p. 622-657, 2011.

FERREIRA, S. G.; VELOSO, F. A. Intergenerational mobility of wages in Brazil. Brazilian Review of Econometrics, v. 26, n. 2, p. 181-211, 2006.

FURTADO, C. Formação econômica do Brasil. São Paulo: Editora Nacional, 1989.

HOFFMANN, R. Distribuição de renda: medidas de desigualdade e pobreza. [s.l.] Edusp, 1998.

HOFFMANN, R. Effect of the rise of a person's income on inequality. Brazilian Review of Econometrics, v. 21, n. 2, p. 237-262, 2001.

HOFFMANN, R. Decomposition of Mehran and Piesch inequality measures by factor components and their application to the distribution of per capita household income in Brazil. Brazilian Review of Econometrics, v. 24, n. 1, p. 149-171, 2004.

KIM, C.; SAKAMOTO, A. The rise of intra-occupational wage inequality in the United States, 1983 to 2002. American Sociological Review, v. 73, n. 1, p. 129-157, 2008.

LARRIMORE, J. et al. Consistent cell means for topcoded incomes in the pubic use march CPS (1976-2007). NBER Working Paper Series, n. 13941, p. 1-53, 2008.

MAIA, A. G. Estrutura de ocupações e distribuição de rendimentos: uma análise da experiência brasileiras nos anos 2000. Revista de Economia Contemporânea, v. 17, n. 2, p. 276-301, 2013.

MAIA, A. G.; MENEZES, E. Economic growth, labor and productivity in Brazil and the United States: a comparative analysis. Brazilian Journal of Political Economy, v. 34, n. 135, p. $212-$ $229,2014$.

MAIA, A. G.; SAKAMOTO, A. Occupational structure and socioeconomic inequality: a comparative study between Brazil and the United States. Economia e Sociedade, v. 24, n. 2, p. 229-261, 2015.

MOUROUGANE, A.; PISU, M. Promoting infrastructure development in Brazil. OECD Economics Department Working Papers, n. 898, p. 1-34, 2011.

PINHEIRO, A. C. et al. Brazilian economic growth, 1900-2000: lessons and policy implications. [s.l: s.n.]. 
ROSE, D.; HARRISON, E. The european socio-economic classification: a new social class schema for comparative european research. European Societies, v. 9, n. 3, p. 459-490, 2007.

SABOIA, J.; HALLAK NETO, J. Salário mínimo e distribuição de renda no Brasil a partir dos anos 2000. Economia e Sociedade, v. 27, n. 1, p. 265-285, apr. 2018.

SAKAMOTO, A. et al. What underlies the Great Gatsby Curve? Psychological micro-foundations of the "vicious circle" of poverty. Mind and Society, v. 13, n. 2, p. 195-211, 2014.

SAKAMOTO, A.; KIM, C. Bringing productivity back in: rising inequality and economic rents in the U.S. manufacturing sector, 1971 to 2001. Sociological Quarterly, v. 55, n. 2, p. 282-314, 2014.

TAYLOR, M. P. Purchasing power parity. Review of Interntional Economics, v. 11, n. 3, p. 436452, 2003.

THE WORLD BANK. World Development Indicators. Washington, D.C.: The World Bank, 2019.

TREIMAN, D. J. Industrialization and social stratification. Sociological Inquiry, v. 40, n. 2, p. 207-234, 1970.

ULYSSEA, G. Informalidade no mercado de trabalho brasileiro: uma resenha da literatura. Revista de Economia Política, v. 26, n. 4, p. 596-618, 2006. 